\title{
USEFULNESS OF SPUTUM GRAM STAIN AND CULTURE FOR DIAGNOSIS OFPNEUMONIA IN A GERIATRIC INSTITUTION
}

\author{
Jean-Jacques Lloveras, Mohamed-Issam Shukr, Claude Pinos, Anissa Lindoulsi, \\ Philippe Grima \\ Centre de Reeducation Fonctionnelle, \\ Bagneres de Luchon, FRANCE
}

\section{SUMMARY:}

The value of bacteriological assessment of sputum samples is controversial during lower respiratory tract infections. We retrospectively studied sputum Gram stain and culture in a geriatric population during a two-year period. A total of 42 sputum samples were send to the laboratory; among them, 24 (57\%) allowed a diagnosis with a predominant morphotype.

Gram positive and Gram negative were equally distributed, but staphylococci and pseudomonas were most frequently found,as it is usually reported in the setting of nosocomial infections.In geriatric units and in long-term care facilities, diagnostic tests for management of lower respiratory tract infections are rarely performed, but the ratio cost-efficacy of this bacteriological testing could be improved, if considered the shortness of evolution of broncho-pulmonary infectious episodes.

Key words: pneumonia, geriatrics, sputum .

\section{INTRODUCTION:}

Broncho-pulmonary episodes are the second cause of nosocomial infections; among bacterial complications, they represent in geriatric patients one of the leading cause of morbidity and mortality. Numerous guidelines recommend not to perform bacteriological studies (ie Gram stain sputum and culture) and to treat patients with Amoxicillin Clavulanate or a third generation cephalosporin without anti-Pseudomonas activity associated with a macrolide or a fluoroquinolone in severe cases. However, in geriatric inpatients, hospital-acquired pneumonia are often caused by different and more resistant pathogens then in the community. In this study, we tried to precise in this setting the prevalence of positive sputum samples and the causative pathogens.

\section{MATERIALAND METHODS:}

During a two-year period, from January 2007 to December 2008, we retrospectively studied all the sputum samples send to the laboratory in a 26-beds unit. Mean age of the patients was 80,5 years, with a mean hospitalization time of 33 days. The samples were collected, if feasible,when a feature of pneumonia was present. Gram coloration and bacterial culture was performed in every sample in the 24 hours after collection, before antibiotic treatment. Microorganisms were identified and sensitivity to antibiotics precised and samples were classified as negative, positive with bacterial pathogens, or positive with yeasts only.

We considered samples as positive if a microorganism was predominant or if two potential pathogens were present.

\section{RESULTS:}

During the study period, 456 patients were admitted, corresponding to 16024 patient-days. Sputum samples have been obtained from 42 patients, corresponding to 9 per 100 admissions and 3 per 1000 patient-days.Among them, 24 $(57 \%)$ revealed a predominant causative microorganisms.

Seven samples (17\%) were strictly negative. A total of 30 bacterial pathogens were identified, equally distributed between Gram positive and negative: Staphylococcus aureus: 14, whose 2 MRSA, Diplococcus Pneumoniae: 2 Pseudomonas: 6; Haemophilus: 4; Moraxella: 1; E.Coli: 1; Enterobacter: 1; Serratia: 1 (cf Fig. 1.). In 11 cases, Candida species was isolated as the only causative microorganism.

\section{DISCUSSION:}

Lower respiratory tract infections are one of the leading cause of morbidity and mortality in elderly (1). Usefulness of sputum Gram stain and culture in community - acquired pneumonia or inpatient setting is controversial. In adults, some guidelines do not recommend to perform this bacteriological test and for some authors, it should be restricted to specific situations, mainly suspicion of drugresistant bacteria (2).

In geriatric patients, sputum examination is rarely performed: in long-term care facilities, a recent study reported only this test in 3,3\% of presumed lower respiratory tract infections (3). In fact, in older subjects,expectoration is rarely present: its occurency has been evaluated to $21 \%$ of cases in a recent study where mean 
age of patients with nosocomial pneumonia was 77 years (4). However, for some authors, when performed, this technique is able to identify a predominant morphotype in 30 to $40 \%$ cases (5). Such values of percentage of positive samples compared to all the examined sputum samples have been found in four others studies $(6,7,8,9)$.

In order to improve reliability of sputum Gram stain and culture, it seems important to process quickly samples et to perform examinations before administering antibiotics (10). Failure of these rules, with absence of sending or examination of the samples appears partially responsible for the low sensitivity of the technique.

However,interpretation of sputum samples must also take into account oropharyngeal colonization with Gram negative bacilli, which is frequent in elderly persons (11). But,in this study, examination of sputum was indicated in presence of a clinical suspicion of a lower respiratory tract infection and Gram negative are well recognized as causative pathogens of nosocomial pneumonia. Staphylococcus aureus and pseudomonas are mainly reported in different studies (4). Moreover, laboratory processing was performed in the 24 hours: despite this, the high proportion of bacteriaassociated Candida isolates in our study is probably in relation with age and immunodepression of the patients,but a delay in processing is associated with a increased number of yeasts isolates. (12).

In this setting of geriatric units or long-term care facilities, cost-efficacy of this test should be evaluated; for that purpose, ratios of number of bacteriological examinations per 100 admissions or per 1000 patient-deys could be used .

\section{CONCLUSION:}

Value of sputum Gram stain and culture is controversial for diagnosis of pneumonia.In a geriatric population,despite a low frequency of feasible examination, sputum examination could be of diagnostic value, particularly in order to isolate a drug-resistant pathogen in a setting of nosocomial pneumonia.

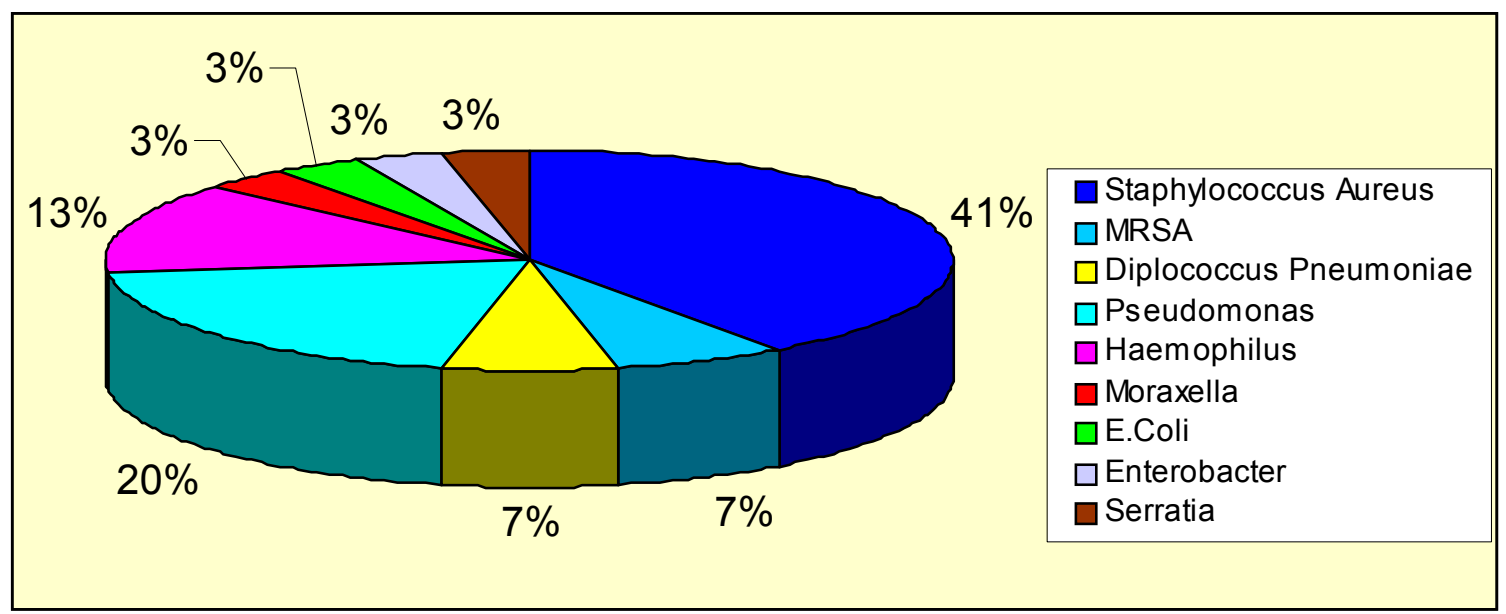




\section{REFERENCES:}

1. MARRIE T.J.: Bronchitis and pneumonia in: Infectious diseases in the aging: a clinical handbook; ed: TT Yoshikawa and DC Norman : Humana Press Totowa; 2001: 53-65

2. MADISON J.M.: Expectorated sputum for Community -acquired Pneumonia; a sacred cow. Arch Intern Med 2004 ; 164: $1725-27$

3. MUBARECKA S, DUCKWORTH $\mathrm{H}$, CHEANG $\mathrm{M}$ et al: Use of diagnostic tests for presumed lower respiratory tract infection in long-term care facilites. J Am Geriatr Soc 2007;55:1365-70

4. SACCHETTI R., APORTI M., BIANCO L. et al: Prospective observational study of pneumonia in a Italian hospital. Infez Med 2008; 16:219-26.

5. WILBER S.T.: Geriatric pneumonia in: Geriatric Emergency Medicine; ed SW
MELDON, OJ MA, R WOOLARD Mc Graw-Hill; 2004:144-53

6. MIYASHITA $\mathrm{N}$, SHIMIZU $\mathrm{H}$, OUCHI K et al: Assessment of the usefulness of sputum Gram stain and culture for diagnosis of community-acquired pneumonia requiring hospitalization. Med Sci Monit; 2008:14:CR 171-6.

7. GARCIA-VASQUEZ E, MARCOS MA, MENSA J et al: Assessment of the usefulness of sputum culture for diagnosis of community-acquired pneumonia using the PORT predictive scoring system. Arch intern Med: 2004 ; 16 :1807-11

8. LEVY M, DROMER F, BRION N, LETURDU F, CARBON C :Communityacquired pneumonia; Importance of initial noninvasive bacteriological and radiographic investigations. Chest:1988;93:43-8

9. ENDEMAN H, SCHELFHOUT V,
VOORN GP, VAN VELZEN-BLAD H, GRUTTERS JC, BIESMA DH: Clinical features predicting failure of pathogen identification in patients with community acquired Pneumonia . Scand J Infect Dis : 2008; 40:715-20

10. MUSHER DM: The usefulness of sputum Gram stain and culture. Arch Intern Med: 2005;165:470-471.

11. VALENTI WM, TRUDELL RG, BENTLEY DW: Factors predisposing to oropharyngeal colonization with gramnegative bacilli in the aged. $\mathrm{N}$ Engl J Med : 1978; 298:1108-11

12. EWIG S, SCHLOCHTERMEIER M, GOKE N., NIEDERMAN M: Applying sputum as a diagnostic tool in pneumonia: Limited yield,minimal impact on treatment decisions. Chest: 2002; 121:1486-92

Address for correspondence :

Jean-Jacques Lloveras

CRF, 5 Cours des Quinconces, 31110 Bagneres de Luchon, FRANCE

Tel : 3305617993 02; Fax : 3305617993 13;

e-mail: jjlloveras@yahoo.fr 